\title{
10 Rupture and Readjustment of Tradition: Personal Autonomy in the Feminised Warlpiri Diaspora in Australia
}

\section{Introduction}

I am very happy to be a part of this festschrift for Ian Keen. Although there is no straightforward connection between this chapter and his intellectual interests, there is a strong connection via his supervision of my doctoral research and the general inspiration of his approach to anthropology. This approach could be summarised as empirically grounded, open to a critical engagement with theoretical developments (neither knee-jerk rejection nor discipleship, more often the deflating of pretensions through open-minded evaluation) and a commitment to a clear style of writing. These elements continue to guide and challenge my own research.

The discovery of a largely feminised Warlpiri diaspora in Australia during 2009-12 has prompted a further reconsideration of Diane Bell's support in the 1970s and 80s for the project of increasing the status and independence of Aboriginal women via a return to traditionalism and traditional country. Many doubts were raised at the time about her characterisation of the relatively high pre-contact status of Aboriginal women (Berndt 1989: 14; Hamilton 1986: 9; Keen 1989: 29-30; Merlan 1988: 26-30; Tonkinson 1990: 141-3), but the present chapter looks instead at the homogeneity of her reported responses to declining 
settlement conditions and her underemphasising of personal autonomy as a break with the constraining relationships that traditionalism entailed. The Warlpiri women of the diaspora decided to leave the remote settlements and make a life for themselves at a distance from the home settlements and their traditional country. This chapter outlines a variety of their projects of personal autonomy: escape from promised marriages, becoming an itinerant camper, being a leader of a Pentecostal church, being the matriarch of a Christian jilimi (widows' camp) in a town camp, being a semi-professional artist in Adelaide, and being a house mother for settlement children attending school in Adelaide. All involved a variety of relationships to tradition ranging from outright hostility to more subtle readjustment.

Although there was an early signal coming from Beckett's account of the Torres Strait Islander diaspora in the 1970s that the position of women would be an issue in other indigenous diasporas (Beckett 1983: 214), that signal became a blinding light in the Warlpiri diaspora research project (2009-12). ${ }^{1}$ I found a largely feminised Warlpiri diaspora throughout Australia. Of the total Warlpiri population of 3,600, I estimated that about one-quarter (900) lived permanently beyond the main Warlpiri settlements in other Aboriginal settlements and in more distant towns and cities, and many other Warlpiri travellers moved between these locations following networks of kin and drinking camps. Among the permanent diaspora the stable households were overwhelmingly run by mature Warlpiri women. Moreover, the Warlpiri women's stories of 'getting away' from their home settlements, strongly infused with the themes of escape and the assertion of their personal autonomy, including the marrying of nonAboriginal men completely outside of their kinship universe, necessitated the thematisation of Warlpiri women as actors in intercultural history. In the same diaspora locations there were also Warlpiri women who had not made decisive choices but drifted to their present locations along seemingly circuitous and haphazard routes. Yet others asserted the prerogatives of personal autonomy, but became dependent upon alcohol or romantically entangled in abusive or exploitative relationships with white men. All of them, however, had made some sort of life for themselves permanently residing away from their home settlements and traditional country.

Thirty years before my research, during the high point of anthropology's response to second-wave feminism, Diane Bell, among others, had presented a quite different model of Aboriginal women's autonomy, one with a decidedly traditionalist orientation towards the jilimi (widows'/ single women's camp), yawulyu (women's ritual) and Jukurrpa (the Dreaming, land-based religion)

$1 \quad$ Australian Research Council Discovery Project (DP0987357) 2009-2012, Indigenous Diaspora: A New Direction in the Study of the Migration of Australian Aboriginal People Leaving Remote Areas. 
(Bell 1978, 1980, 1983, 1985; Bell and Ditton 1980; Bell and Nelson 1989). She characterised the alleviation of Aboriginal women's subordination in contemporary settlement life as a return to what she controversially argued was Aboriginal women's greater autonomy and more equal status in the pre-contact past. ${ }^{2}$ This characterisation allowed for a propitious alignment of a feminist critique of Aboriginal women's contemporary circumstances, the traditionalist predilections of her main informants and recuperative government projects of land rights, the outstation/homelands movement and the recognition of some aspects of customary law. Baldly stated, Bell's work presented an ideal of Aboriginal women's liberation as following Aboriginal law and the sustaining values of service to kin on a family outstation/homeland on traditional country with secure title.

The juxtaposition of orientations I have outlined here - to homeland outstation versus to the diaspora - therefore raises many issues of historical transformation over the contact period, particularly since the 1970s, but also variation in the capacity to exercise autonomy and the variety of Aboriginal women's projects aimed at achieving greater personal autonomy. In this chapter, I want to explore in some detail the diversity of Warlpiri women's projects of diaspora, that is, the various ways they have found to sustain a life permanently at a distance from the homeland settlements. In this way I hope to develop a greater understanding of the nature of Warlpiri women's active and constructive agency (and its opposites) in the Warlpiri diaspora. This will initially involve an examination of the variety of ways Warlpiri women have taken their leave of the home settlements, something that was beyond the achievable horizon of most of Bell's informants, like Warlpiri ritual leader Topsy Napurrula Nelson, who was deeply embedded in settlement life and in her mature years worried about who would look after her father's traditional country in a more remote area beyond her home settlement (Bell 1985; cf. Nelson 1990).

In addition to the sometimes dramatic action of leave-taking, the Warlpiri women of a later era sometimes entered a period of precarious, free-form living among the 'long-grassers' of Darwin (dwellers in makeshift camps on secluded vacant land near the city), or in the unofficial camps of Katherine and Alice Springs or the parklands of Adelaide. Of those who survived this period and regained

2 For reasons of limited space I do not wish to rehearse the evidence presented to challenge Bell's most disputed claims about the relative autonomy and equality of Aboriginal women in the pre-contact era and the mostly sceptical reactions of other regional specialists (see, for example, Berndt 1989: 14; Hamilton 1986: 9; Keen 1989: 29-30; Merlan 1988: 26-30; Tonkinson 1990: 141-3). Merlan has provided a balanced and scholarly review of the issue and has been at pains to untangle the conflation of homosociality and equality (Merlan 1988, 1992). Bell has never made a detailed or convincing reply to the critiques of her view of the pre-contact era (but see her more general reply to her critics, Bell 1993: 273-306). To be clear, I am not trying to engage with all of Bell's arguments about the marginalisation of Aboriginal women in Australianist anthropology, many of which were justified. 
their sobriety, some became the matriarchs of households in the town camps. In Bagot Camp in Darwin some of these matriarchs became the cornerstone of a Pentecostal church. In Alice Springs some of them recreated a jilimi (widows'/ single women's camp) in new circumstances. The other projects described will be the maintenance of relationships with a white art wholesaler in the diaspora and an unusual project of fostering children from the home settlements for schooling in the city. Before describing those projects, however, it is necessary to attempt some conceptual clarification about the terms 'agency' and 'personal autonomy'.

\section{Conceptual Clarification}

In suggesting 'personal autonomy' and 'active and constructive agency' as relevant categories of analysis I am aware of the pitfall of naïve voluntarism creeping in. I am, however, encouraged by recent clarifications of philosophers, including feminist philosophers, conceptualising personal autonomy as a particular kind of competency of a fully socialised individual and as a matter of degree (see, for example, Friedman 2003; Kühler and Jelinek 2013; Meyers 1989, 1997). Friedman, for example, in defining personal autonomy in terms of 'reflecting on one's deeper wants, values and commitments, reaffirming them and behaving and living in accordance with them even in the face of at least minimal resistance from others' (Friedman 2003: 99) acknowledges varying individual capacities and social spaces for such reflection. In the same way, adopting the idea of non-routine actions that strive to create something, what I have called active and constructive agency (or, more succinctly, 'a project'), does not deny that such agency is always part of the making and remaking of larger social and cultural formations (Ortner 2006: 129-53).

In using these concepts in the analysis of intercultural history, one does not have to deny that personal autonomy may be viewed as a peculiar development of Occidental modernity with its pressures on everyone to be a distinct person, an individual capable of moral judgement and a citizen with legally recognised rights and responsibilities. Giddens also suggests a further development of this trajectory is the rise in late modernity of 'the project of the self' (Giddens 1991). Taken at face value, therefore, the rise of personal autonomy among an encapsulated indigenous population could be seen as an index of transformation to modern subjectivities. Such overgeneralised characterisations are challenged by accounts of what could be called constrained personal autonomy, most influentially by Myers (1986). While his insistence upon autonomy and relatedness as central tensions in Aboriginal desert society has sometimes been inaccurately portrayed as a cultural trait of respect for personal autonomy, Myers himself was careful to identify certain inherent contradictions. 
He conceived of personal autonomy as an achievement of the final stage of the maturation of men who, because of the extension of their network of relations and the growth of their traditional knowledge, could become someone who was recognised as being able to look after others. Interestingly, Bell presents a similar model of Aboriginal women's autonomy increasing with age, for example, in the lack of choice of the first marriage partner followed by a greater choice in subsequent marriages (Bell 1980).

Both would appear to be aligned with the concept of personal autonomy as competent performance of social relationships. Yet, especially for feminist philosophers, there is also a sense in which personal relationships can be a hindrance to personal autonomy which, for someone wishing to question basic presuppositions or norms, can only be achieved through the severing of social ties. It is this dual-aspect personal autonomy - escape from constraining relationships/mastery of social relationships - which has been most apposite for the following case studies.

\section{Background to the Ethnographic Examples}

Since most of the Warlpiri women mentioned in the ethnographic examples left their home settlements after the period of Bell's most intensive period of interaction with the women of Ali Curung between the mid-1970s and the mid-1980s, questions of generational change arise. Perhaps the most significant thing to register is that despite the great successes of the Warlpiri in achieving land rights and the initial success of the outstation movement through the 1980s, seemingly intransigent problems of unemployment, alcohol abuse and violence against women have meant a continuing decline in social conditions on settlements, notwithstanding that liquor restrictions made them more liveable than the towns, at least for the non-drinkers. Occupation of the outstations has dramatically declined partly due to funding restrictions and policy changes (Kerins 2009) but also, I suspect, because the knowledgeable old men and women who were their most ardent supporters have been passing away. The rate of such deaths seems to have accelerated with epidemics of diabetes, heart disease and substance abuse. Mortuary rituals are now the most frequent ceremony performed (Glaskin et al. 2008). Fundamental demographic changes have been taking place which mean that there are now fewer older people to care for and socialise the growing percentage of the young. The passing of the generation who grew up in the desert has also revealed problems of the transmission of detailed knowledge about the country and associated rituals (Curran 2010; Peterson 2008). Initiation ceremonies continue but in a somewhat truncated form. At the same time there has been a rise in Western Desert-style painting as fine art in the international art market (Myers 2002) and, as we shall see below, this has influenced other 
art markets providing a supplementary economic basis for the diaspora, which is otherwise predominantly sustained by portable welfare payments and public housing. As we shall also see, the continuing government project of education on the settlements, while now hobbled by widespread disengagement, was for some the inspiration and means of their diaspora lives.

\section{Ethnographic Examples of Warlpiri Women's Diaspora Projects}

\section{1. 'Getting Away'}

The first set of examples covers the dramatic escape from promised marriage at the remote settlement of Lajamanu. They provide the clearest cases of projects of personal autonomy as focused action to avoid conforming to norms on the settlement and resisting the exercise of power over them. These will be contrasted with other forms of leave-taking which did not have the character of resistance; rather, they demonstrated mastery of prevailing cultural constraints and the successful calibration of action to manoeuvre around constraining forces. Finally, the focused action of escape will be contrasted with the more diffuse negotiation of life as a long-grasser.

I should make it clear that my informants were middle-aged women who were recalling their youth in the late 1960s to 1980s when community support for the fulfilment of marriage promises, including the sanction of physical violence against the reluctant girl, was still very much in evidence. Generally speaking, today there is a different balance of forces that has resulted in a much looser attitude to enforcement of promises, a movement away from the traditionally most preferred kinship categories for spouses and the weakening of the ideal of long-term relationship (Bell 1980; Burbank 1988; Musharbash 2010). It was in fact the early pioneers of the Warlpiri diaspora who had opened up the possibility of escape to geographically and socially distant places like Alice Springs, Katherine and Darwin.

Perhaps the most dramatic story was of two young women, who secretly saved up their wages from teacher assistant jobs (or, according to another version of the story, the winnings from card games) and booked a direct flight from Lajamanu to Darwin, a distance of 890 kilometres. In the execution of the plan they had enlisted the help of their school principal and the settlement bookkeeper, who were sympathetic to them as the victims of fairly sustained physical violence from the promised husbands, particularly when drunk. One of them had sheltered in the principal's house more than once. The secrecy of the 
plan, the lack of direct involvement of their Aboriginal kin and the swiftness of its execution was intended to limit any retaliation against their kin and also to avoid alerting those whom they knew would not support them.

The brutality of the beatings typically played a part in arousing the sympathy and support of key kin, usually a mother or sister, and also the support of white settlement staff. A relevant broader context for the white staff was probably the slowly changing attitudes to domestic violence in the broader community during the 1970s and 1980s (Laing 2000). This meant that in one case, after a long series of violent incidents, one young woman at Lajamanu was given a police escort to a waiting plane then flown to Darwin and delivered to a women's shelter there. Other stories revealed more opportunistic and zigzagging routes to the diaspora location involving things like a lift with a sympathetic visiting truck driver, hitchhiking with white strangers or sympathetic young Aboriginal men heading for a Darwin adventure, short stays with relations along the way and sometimes repeated attempts after recapture by relations.

Another form of 'getting away' for a few in the late 1970s was elopement with a white partner. Two of these cases involved white male teachers who had arrived in the settlement with their own white partners. Similarly careful planning for a sudden departure was involved and in one case there were heightened concerns about taking a young Aboriginal son with the eloping couple. The anticipated strong negative reaction from the in-laws of the Warlpiri woman was partly because of the strength of the Warlpiri husband's family who would not only have to endure the breakup of the relationship but the taking of the young boy without their approval. In the other case, the Warlpiri woman left her young children behind when she went to Darwin to be with the white teacher. This case was viewed rather bitterly by her kin as abandonment.

Other instances of 'getting away' involved a Yuendumu woman leaving after a beating inflicted by her in-laws who accused her of 'running around' (having adulterous affairs), and a Willowra woman who left after her husband took a second, younger wife. Sometimes the women simply wanted to end a constraining relationship and pursue other more exciting possibilities. These separations tended to be the most difficult to achieve because, like the younger escapees, they required a degree of boldness, orchestration of support, tenacity and, ideally, having close kin already established in the diaspora location who would be willing to receive them. One woman's departure to Alice Springs from Yuendumu followed her husband's non-attendance at her brother's funeral, an unforgivable solecism in the view of her kin thus ensuring their support for her. Another moderated a potential backlash for leaving a husband by attaching herself to her daughter's household in Alice Springs and helping her look after her young children, her own grandchildren. 
The dual notion of personal autonomy was nowhere more apparent than when those who had escaped their promised husbands in Lajamanu arrived in Darwin. The accomplishment of their escape plan was typically not matched by any detailed plan about how they would live in Darwin. Instead, they sought out the few kin who were already there. One was a Warlpiri man who had stayed on in Darwin after working for the Aboriginal Army Corps in the Second World War and married a Tiwi Island woman. This Warlpiri pioneer appeared in many of the stories about the Warlpiri in Darwin, sometimes offering shelter in his own modest house at Bagot Camp and, critically, transforming the visitors from strangers into quasi-kin by introducing them to his in-laws - a potentially momentous joining of two separate kin networks. A number of young Warlpiri women, attracted to the life of long-grassers, with their free attitude to sexual partners and liquor, made a precarious life for themselves, in true bricouleur fashion, out of the bits and pieces that were around: the drinking partner who became a 'husband', whose relations in Darwin shared food and liquor with them when they could; the YMCA where one could shower; the friendly taxi driver who might give credit; a scrounged scrap of plastic for a tarpaulin; a second-hand mattress; the occasional gift of fresh fish from anonymous white people; lunch at the soup kitchen; wild drinking and dancing nights at the club favoured by Aboriginal people; the occasional sale of a painting. In other words, this was a much less ordered existence than the one described by Sansom at a different unofficial camp on the outskirts of Darwin in an earlier era (Sansom 1980, 1988, 2010).

Although drinking partners and 'husbands' changed often, some of the intertribal relationships did endure and part-Warlpiri children would grow up back on the father's settlement in Arnhem Land. Generally, though, among the long-grassers relationships seemed to be more negotiable. The whole raison d'être of the long-grass camps was to be free of all sorts of inhibiting restrictions, although some traditional prohibitions die hard. One Warlpiri woman enjoying her newfound freedom of selecting her own partners could not quite bring herself to have a permanent relationship with an unrelated man from another desert tribe who happened to have the same subsection name as her, in theory a possible brother.

\section{The Pentecostal Churchgoers at Bagot Camp, Darwin}

A number of Warlpiri women did not survive as long-grassers. Some died prematurely because of the rigours of the lifestyle, others died in violent incidents and another spent 10 years in jail for a homicide. The middleaged Warlpiri women I found at Bagot Camp in 2009-12 were the survivors who, through emotional exhaustion or health crises or religious conversion, had regained their sobriety and some control over their lives and now ran 
functioning households in the camps (cf. Brady 1995). A few had joined forces with two white Assemblies of God missionaries and had become elders in the local Pentecostal church in the camp. They became partners in the project of sustaining the church against all the odds: the congregation was relatively small (I would say less than 100) putting pressure on the same core group, the pace of conversions seem to be fairly sedate and moreover, their functioning households in camp continued to be a destination for hard-core drinkers and a reception centre for kin visiting Darwin for business or pleasure or just passing through. I estimated the core group to be about five Aboriginal and five non-Aboriginal people. During the week they would organise Bible study groups, band and choir practice, informal prayer meetings at people's houses and good works such as prison visits. The climax of the week would be the Sunday service at the meeting centre in the camp.

It was during the testimonials at the Sunday service that I heard the most dramatic and forthright challenge to Aboriginal traditions. The three middleaged Warlpiri women I saw at the service had belonged to the Baptist church back on the Warlpiri settlements, and that church had generally taken a nonconfrontational attitude to traditional rituals and had taken on some indigenised modes of evangelisation (see, for example, Jordan 2003). Two of the women had been on a long journey since then. One, on becoming a widow in Lajamanu, had taken up the drinking life first in Top Springs, then Katherine and then at Bagot in Darwin before being 'saved'. The dramatic change in her life to become the sober elder in the church and head of a functioning household still seemed something of a surprise to her. Another had left Ali Curung after the unsettling premature death of her adult daughter and had taken some of the grandchildren with her to put them through school in suburban Darwin. She had first attended a Baptist church in Darwin but was shocked when no one in the unfamiliar congregation spoke to her. She then joined the more intimate and welcoming Assemblies of God congregation at Bagot where she found other settlement women like her. One of these women in her testimony specifically denounced the prototypical male Aboriginal sorcerer: 'He did not heal me. He is a liar and a thief. I got out of that system, praise the Lord.'

This was not an aberration, but reflected the doctrinal approach of all Pentecostal churches including the Assemblies of God (McDonald 2001: 66; Ono 2007; Robbins 2004: 127-30). Occasionally, a drunken Aboriginal man wandering past the open service would briefly remonstrate with the women for expressing such views. In that moment the women, with the support of each other and of their congregation and church, were undeterred. In one sense, the form of their challenge to traditional law represented the most radical statement of rejection of traditional male authority (in favour of the authority of the Lord). In other respects, however, the Warlpiri women involved in the church retained 
aspects of homeland settlement traditionalism: they maintained their Warlpiri language, they participated in the continual testing of kin relations through making demands and responding to demands for generosity (demand sharing), they retained traditional knowledge of their own traditional country beyond the homeland settlements and they organised traditional mortuary rituals in the town camps.

Their defiance of sorcery, though, placed them well outside the vast majority of contemporary Warlpiri people who continued to believe in the ubiquity and efficacy of sorcery. It seems unthinkable that someone like Topsy Nelson would ever have embraced such a religion. Their denunciation of Aboriginal law in the context of the service was in some ways a competent enactment of social relations since it met the expected format and mode of expression favoured by the church. Indeed, it is the relatively simple formulations and lack of extended training that some anthropologists see as easing the spread of Pentecostalism (Robbins 2004: 130). But in the broader context of Warlpiri society, their denunciations marked a dramatic challenge to well-entrenched social norms and a defiance of the powerful interests of senior male ritual leaders.

\section{The Jilimi in the Alice Springs Town Camp}

While there were a surprising number of commonalities between the matrifocal households in Bagot and in the town camps of Alice Springs, I labelled one of those households in Alice Springs a jilimi (the name for the traditional widows' / single women's camp) because its matriarchs seemed to be more self-consciously attempting to establish a women's space and to use their traditional prowess in hunting and gathering, Warlpiri language and traditional culture to extend their social networks and differentiate themselves from the local Arrernte people. The fact that the leading matriarch was an elder in the Alice Springs Baptist church allowed them to avoid the overtly confrontational approach to Aboriginal law required by the Pentecostals. Rather than confrontation, her Christian beliefs would sometimes disappoint expectations of her kin, for example to be involved in violently prosecuting family feuds. Instead they prayed outside the courthouse during the associated criminal proceedings. At other times their Christianity provided a means of avoiding direct confrontation, as in praying for the drinkers who sometimes congregated outside their yard, that they would drink quietly and not become violent during the night.

Despite the difficulties of life in the town camp, the core Warlpiri women of the jilimi had all given up thoughts of returning permanently to Yuendumu or of marrying again (they were in their late 50s and early 60s). And, although the course of their pre-conversion lives had been subject to some common vicissitudes (violent relationships, alcohol abuse, jail, motor vehicle accidents) and continually encroaching family dramas, I interpreted their jilimi as a new 
kind of Warlpiri project: to live out the greater autonomy, bequeathed by their mature age, in Alice Springs rather than at Yuendumu or some remote outstation. Emblematic of this project was their cultivation of a friendly Indian taxi driver who would take them out to their favourite hunting grounds just south of Alice Springs. There, they could escape the immediate pressures of the town camp, have a picnic, go hunting for goanna and collect bush medicine which was still familiar to them from their own traditional country hundreds of kilometres to the northwest. They converted the Baptist congregation to their love of hunting and persuaded church members to provide transport for hunting trips to the northwest of Alice Springs after the Sunday morning service. The hunting trips become part of the established Sunday routine. The Warlpiri women's involvement with the overwhelmingly non-Aboriginal Baptist congregation, some of whom had strong links to Yuendumu from its very beginning in 1946, was in my view highly significant in sustaining the Warlpiri women. In particular, the matriarch of the jilimi, who was also an elder in the church, had many supportive friends and acquaintances and undertook official church work of visiting Warlpiri hospital patients and prisoners and praying over them. The core women of the jilimi also rode the wave of the self-determination policy which resulted in the 1980s in a proliferation of Aboriginal organisations in Alice Springs in which they became valued participants, for example, as students in literacy courses at the Institute for Aboriginal Development, producing traditional paintings at Jukurrpa Artists and in providing Warlpiri content for the Warlpiri students in the new 'two-way' Aboriginal primary school (Yipirinya School).

They were not alone. There were a number of middle-aged Warlpiri women and their children in Alice Springs at the same time enabling them to provide support at critical times such as the various stages of mortuary rituals and to take advantage of opportunities to assert their traditional cultural repertoire, for example, traditional dancing at cultural festivals in Alice Springs. In these activities and in their hunting they occasionally exhibited a somewhat chauvinistic attitude towards the local Arrernte people whom they pitied because, they said, unlike the Baptists, the Catholic missionaries had stopped their traditional women's dancing. They did not bother consulting the local Arrernte people about where they could hunt near Alice Springs, reasoning that the Arrernte were now focused exclusively on store-bought food. Indeed, resurgent Arrernte pride following a successful native title claim to the land around Alice Springs had begun to provoke retaliative calls for badly behaving 'visitors' to return to their own country. ${ }^{3}$

3 See, for example, comments by Darryl Pearce, then CEO of Lhere Artepe, the Arrernte native title corporation, quoted in The Australian newspaper 24 May 2009 and a series of TV community service announcements produced by Lhere Artepe and broadcast on local TV in 2009 (available on YouTube as Lhere Artepe Respect 1, 2 and 3 TVC by Bellettemedia). 
The cultural assertiveness and self-direction of the Warlpiri matriarchs in the town camp jilimi are similar to that described in Bell's account of the Kaytej jilimi at Ali Curung in the 1970s (Bell 1983). What seemed to be missing in Alice Springs were the career 'businesswomen' (ritual specialists) who, when freed of child-minding duties in their middle age, would pursue the advancement of their knowledge of and ability to perform yawulyu ceremonies. The competitive efflorescence of such ceremonies, described by Bell and later by Dussart at Yuendumu (Dussart 2000), was absent in Alice Springs. The relative stability of the jilimi household attracted near-senile parents, dialysis patients and Warlpiri visitors who were passing through and looking for a relatively safe place to stay. It also became a contact place for child welfare workers looking for foster parents for neglected Warlpiri children. In this respect, they remained very much part of a kin-based service economy described by Merlan and others (Merlan 1991; Sansom 1988) and had to cope with the relentless challenges of provisioning their immediate needs in the lean week following their fortnightly welfare payment.

\section{The Warlpiri Children's House in Adelaide}

In Adelaide I met a Warlpiri woman from Ali Curung who had been living in Adelaide for about 20 years. She had known and revered Topsy Nelson and had known Diane Bell when she was doing her fieldwork in Ali Curung. Her story, while exceptional, provides a dramatic counterpoint to Bell's account, for despite her respect for the traditionalism of Topsy Nelson and the traditionalism of her own fathers and other legendary figures such as Engineer Jack, she decided to leave.

She had no children of her own and over a period of 20 years she and her white husband from Adelaide hosted 65 Aboriginal children from Ali Curung for varying periods of time so that they could attend school in Adelaide. This remarkable project was conceived and operated outside of any targeted government program. ${ }^{4}$ It was the labour of love of four key individuals: the 'mother' (stepmother) who was an Aboriginal police aide back in Ali Curung, her daughter (stepdaughter) who had gone to Adelaide to further her education, the daughter's non-Aboriginal husband who supported the project (cf. Batty 2005) and, quite fortuitously, the white ex-principal of Ali Curung school who had retired to Adelaide. The education project could alternatively be conceptualised as one of sustaining long-term relationships with significant non-Aboriginal people (see below).

4 It was funded unofficially by virtue of the payment of carer's benefit for looking after the children concerned. Other major sources of income for the project included the private income of the non-Aboriginal husband and the ex-Ali Curung school principal. 
The ex-principal's extraordinary generosity in devoting his time and a high percentage of his financial resources to helping his grown-up ex-pupil settle into Adelaide means that he could be seen as the midwife of the Ali Curung diaspora in Adelaide. More accurately though, this small corner of the Warlpiri diaspora was the result of the confluence of a number of factors, including a very different range of responses of the young woman to the circumstances of Ali Curung in the 1980s. She was alarmed at the promised marriage prospects she was facing as she grew up at Ali Curung. While her own respected father, who was a leader in the land rights and outstation movements, was a non-drinker, her prospective promised husband had become a hopeless alcoholic. I doubt whether she would have been moved by Bell's balancing comments about the system as a whole - that in subsequent marriages there would be a greater degree of personal choice involved (Bell 1980). Moreover, with the support of her family, she had succeeded in the education available on the settlement and to an unusual degree had adopted the message of education as her own. It is now difficult to reconstruct the sequence of her leave-taking. Critically, however, she had the support of her influential father to postpone her promised marriage and further her education in Adelaide where she linked up again with her old school principal.

There is no written manifesto of the school education project but it was expressed in 'two laws talk' (cf. Austin-Broos 1996; Harris 1990) and it was clear that they aspired to produce bicultural individuals (cf. Pearson 2009: 292-300). It was always envisaged that following the completion of their school education the visiting children would return permanently to Ali Curung. They all visited Ali Curung on a yearly basis. Sometimes included in that visit would be spending time at the deceased father's outstation where they received some instruction in traditional culture from his widow. The non-Aboriginal husband had been increasingly drawn into the ceremonial life of the settlement over the course of these return visits. The emblem of this group, with its frequent orbiting back to the settlement and ferrying children to school, could be its small bus purchased via a personal loan that stretched the resources of the household.

\section{The Adelaide Warlpiri Women Artists}

In this example the project of sustaining a long-term relationship with a significant non-Aboriginal person, their art wholesaler, is bound up with a project of economic independence as semi-professional Warlpiri artists. The relationship began rather fortuitously when they were introduced by a former settlement art adviser who was not himself in a position to help. From humble beginnings the art wholesaler had developed a relationship with four Warlpiri women artists and in 2009-12 that relationship had become one of the dual economic foundations of those Warlpiri women's existence in Adelaide. 
The other economic foundation was the welfare system, which they continued to rely upon for housing and other necessities. They received a few hundred dollars for each canvas they completed, typically one or two a week, thereby doubling their welfare income. This allowed them to buy food and clothes they liked, even during the lean week after the fortnightly welfare payment, to purchase motor vehicles, to send money to relatives and occasionally to indulge their favoured vices. Their physical distance from most of their relations enabled some circumvention of opportunistic demand sharing, although the increasing incidence of mobile phone ownership was encroaching upon that. Even so, it seemed to me that their circumstances in Adelaide enabled unprecedented personal autonomy which I observed first-hand when one of the four artists arrived back from Melbourne, having broken up with her partner, with literally no possessions. Ill and penniless and without access to welfare payments, which she had diverted to paying off a car (long since broken down), she commenced painting in a small spare bedroom of a Warlpiri relation in Adelaide. By the end of the week she had replenished her wardrobe with the proceeds of one painting and purchased a car with another painting.

The relationship with the art wholesaler endured primarily because their project of relative economic independence coincided with their art wholesaler's own project of economic independence. Both were reliant on the fickle flows of changing tastes in the international and national art market and cyclical fluctuations in the disposable income of art purchasers. Critically, the wholesaler had chosen to deal with artists whose work he thought he could sell and had developed a niche of affordable Aboriginal art which was to some extent insulated from the wilder fluctuations of the high-end fine art market. His relationship with one of the most successful artists, a former Aboriginal teacher assistant, sometimes came under strain when she tried to enlarge their relationship into advancing loans and assisting with sundry everyday problems and family crises. He resisted these pressures and relied instead upon his consistent payment, honest dealing and a much appreciated annual artist residency he organised for some of them to spend time in an art gallery at Yulara in the Northern Territory. From there they could more easily visit their relations in Alice Springs and back at Mount Allen, their home settlement. For their part, the Warlpiri artists were broadly loyal to the art wholesaler, but to varying degrees. Their immediate needs sometimes overrode the logic of maximising price by having an exclusive agent, and they seemed to enjoy the flexibility that such occasional freelancing gave them. 


\section{Those with Little Personal Autonomy or Constructive Agency}

Thus far I have been describing those women in the diaspora who have taken some positive action in various projects of personal autonomy and self-direction. In this section I wish to briefly outline the other side of the Warlpiri diaspora: those who are drifting or stuck or who have entered into such controlling relationships or drug dependency as to severely limit any capacity for personal autonomy or active and constructive agency. There are those already mentioned who gather around the functioning households of the matriarchs in town camps and the suburbs of towns and cities: the alcoholic relations, the frail elderly, unemployed adult children and adopted grandchildren. There are also the committed drinkers who have their own network of drinking camps and drinking households around Australia. They sometimes move in and out of the networks of their kin in more functioning households, but are more likely to be found in the long grass of Darwin, the unofficial camps around Katherine, Tennant Creek, Alice Springs, Mount Isa and Cairns and the parklands of Adelaide.

The idea of sustaining a household to enable its residents to drink is still a project of minimal agency for the few who occasionally have to deal with welfare housing authorities and NGOs specifically established to support fragile tenancies. Even that minimal agency broke down in the case of those whose health problems become severe because of their years of drinking and self-neglect. They were sometimes given priority for welfare housing, notwithstanding a background of damaged and abandoned houses. On reflection, it is not always easy to clearly separate the sober projects of personal autonomy described previously and dissolute dependency. In some instances these worlds overlap, for example, when independently derived income from jobs or from painting is channelled exclusively into drinking parties or poker machine addictions. There are also inherently problematic cases of dependency in projects of sustaining intimate relationships with non-Aboriginal men, since some of them seem to have involved unfulfilled aspirations for romantic love intertwined with the surrendering of independent income from painting.

\section{Conclusion}

I commenced this chapter by asserting a contemporary heterogeneity of Warlpiri women's approaches to projects of personal autonomy, especially against the return to traditionalism and traditional country advocated by Bell and her key informants. Looking back at the momentous era of the 1970s and early 1980s it is now easier to see how the neat alignment of Bell's view of 
the pre-contact era and the policy agenda of land rights and outstations would obscure the variety of ways Warlpiri women would respond to the challenges of deteriorating settlement life. Bell was, of course, well aware of the extraordinary pressures on Aboriginal women and courageously brought to the surface issues of drunken violence against women and intra-racial rape (Bell and Ditton 1980; Bell and Nelson 1989). But the predilections of her key informants and relatively sedentary fieldwork predisposed her account (along with all accounts based on community studies) towards those Aboriginal women who sought out the available degrees of personal autonomy locally rather than by leaving. ${ }^{5}$ Locating those women who did leave the settlements has not only enabled the enlarging of our knowledge of the kinds of Aboriginal women's responses to their circumstances; it has also provoked a closer examination of the concepts of personal autonomy and of active and constructive agency.

In identifying the Janus face of personal autonomy as both the competent performance of social relationships and sometimes the deliberate fracturing of constraining relationships, it becomes clear that Bell's general orientation underplayed the latter. In the Warlpiri diaspora this kind of assertion of personal autonomy was most commonly exemplified in the many stories of escape from promised marriage. Once the immediate infringement of their intimate personal autonomy had been avoided they assumed a different mode of action, more spontaneously responding to quotidian necessities. There were certainly no grand plans of disappearing into white society. In most cases, the rejection of a particular promised husband did not involve a more general rejection of all aspects of traditional life (just of some aspects as they applied to them).

All of the projects described had the character of a repositioning with regard to some traditional norms and the creation of a new mix (like choosing from a menu) of elements that make up their contemporary Warlpiri life. In the case of the Warlpiri artists of Adelaide, the distant location of their project of economic independence and less constrained consumption moderated the immediate impact of demand sharing. The schoolchildren's household gave prominence to Western-style education and the continuing development of a 'two laws' or bicultural project, which had started on the settlements but the required discipline of the children was easier to maintain in a supportive household in the city. The Alice Springs jilimi brought the idiom of Christianity to the operation of a traditionally sanctioned women's space. It can be noted that all

\footnotetext{
5 I should make it clear that even in the 1970s there were some Aboriginal women known to Bell who had married white husbands, although her focus on settlement life and its ritual would have precluded her making their acquaintance and obtaining their perspective. Also, the limits of Bell's traditionalist focus became a theme in the initial reception of her work. Hamilton, for example, wondered why the implications of the broader societal revaluation of traditional culture in the post-assimilationist period, including women's ritual, was not more explicitly thematised (Hamilton 1986: 13-15).
} 
of these projects have their counterparts on the settlements. But for a variety of reasons the women involved have found their projects easier to sustain away from their home settlements and traditional country.

The denunciation of some key aspects of tradition and male authority by the Warlpiri Pentecostal women, at least in their testimonies during Sunday services, represents the most extreme version of personal autonomy in rejection mode. In the boldness of their self-assertion I see them as the diaspora counterpart to some of the separatist elements of Bell's account of the personal autonomy of mature Aboriginal women organising their own lives in the jilimi or on the outstation, conducting their own healing ceremonies and rituals sustaining the sacred local landscape without the mediation of men. The appearance of the Warlpiri Pentecostal women as a thoroughgoing, modernising women's liberation movement must, however, be tempered with their continued embeddedness in a domestic moral economy of the service mode and the paradoxical preservation within Pentecostalism of beliefs about the reality and power of a spiritual realm. As Robbins has pointed out, it is the preservation of such beliefs that distinguishes Pentecostalism sharply from other modernising projects such as development (Robbins 2004: 128-9).

\section{References}

Austin-Broos, D. 1996. 'Two Laws', ontologies, histories: ways of being Aranda today. The Australian Journal of Anthropology 7: 1-20.

Batty, P. 2005. Private politics, public strategies: white advisers and their Aboriginal subjects. Oceania 75: 209-21.

Beckett, J.R. 1983. Ownership of land in the Torres Strait Islands. In N. Peterson and M. Langton (eds), Aborigines, Land and Land Rights, pp. 202-10. Canberra: Australian Institute of Aboriginal Studies.

Bell, D. 1978. For our families: the Kurundi walk off and the Ngurrantiji venture. Aboriginal History 2: 32-62.

Bell, D. 1980. Desert politics: choices in the 'marriage market'. In M. Etienne and E. Leacock (eds), Women and Colonisation: Anthropological Perspectives, pp. 239-69. New York: Praeger.

Bell, D. 1983. Daughters of the Dreaming. Sydney: McPhee Gribble/George Allen and Unwin. 
Bell, D. 1985. Topsy Napurrula Nelson: teacher, philosopher and friend. In I. White, D. Barwick, and B. Meehan (eds), Fighters and Singers: The Lives of Some Australian Aboriginal Women, pp. 1-18. Sydney: Allen and Unwin.

Bell, D. 1993. Daughters of the Dreaming. Second edition. St Leonards, NSW: Allen and Unwin.

Bell, D. and P. Ditton. 1980. Law: The Old and the New: Aboriginal Women in Central Australia Speak Out. Canberra, ACT: Published for Central Australian Aboriginal Legal Aid Service by Aboriginal History.

Bell, D. and T.N. Nelson. 1989. Speaking about rape is everyone's business. Women's Studies International Forum 12: 403-16.

Berndt, C.H. 1989. Retrospect, and prospect: looking back over 50 years. In P. Brock (ed.), Women, Rites and Sites: Aboriginal Women's Cultural Knowledge, pp. 1-20. Sydney: Allen and Unwin.

Brady, M. (ed.). 1995. Giving Away the Grog: Aboriginal Accounts of Drinking and Not Drinking. Canberra: Drug Offensive, Commonwealth Department of Human Services and Health.

Burbank, V.K. 1988. Aboriginal Adolescence: Maidenhood in an Aboriginal Community. New Brunswick: Rutgers University Press.

Curran, G. 2010. Contemporary Ritual Practice in an Aboriginal Settlement: The Warlpiri Kurdiji Ceremony. PhD Thesis, The Australian National University, Canberra.

Dussart, F. 2000. The Politics of Ritual in an Aboriginal Settlement: Kinship, Gender, and the Currency of Knowledge. Smithsonian Series in the Ethnographic Inquiry. Washington, DC: Smithsonian Institution Press.

Friedman, M. 2003. Autonomy, Gender, Politics. Oxford: Oxford University Press.

Giddens, A. 1991. Modernity and Self-Identity: Self and Society in the Late Modern Age. Cambridge: Polity.

Glaskin, K., M. Tonkinson, Y. Musharbash, and V. Burbank (eds). 2008. Mortality, Mourning and Mortuary Practices in Indigenous Australia. Surrey: Ashgate.

Hamilton, A. 1986. Daughters of the imaginary. Canberra Anthropology 9: 1-25.

Harris, S. 1990. Two-Way Aboriginal Schooling: Education and Cultural Survival. Canberra: Aboriginal Studies Press.

Jordan, I. 2003. Their Way: Towards an Indigenous Warlpiri Christianity. Darwin: Charles Darwin University Press. 
Keen, I. 1989. Aboriginal governance. In J.C. Altman (ed.), Emergent Inequalities in Aboriginal Australia, pp. 17-42. Sydney: Oceania Monographs, University of Sydney.

Kerins, S. 2009. The First-Ever Northern Territory Homelands/Outstation Policy. CAEPR Topical Issue No. 9/2009. Canberra: Centre for Aboriginal Economic Policy Research, The Australian National University.

Kühler, M. and N. Jelinek. 2013. Autonomy and the Self. Philosophical Studies Series. Dordrecht and London: Springer.

Laing, L. 2000. Progress, trends and challenges in Australian responses to domestic violence. Issues Paper 1. Sydney: Australian Domestic and Family Violence Clearinghouse, University of New South Wales.

McDonald, H. 2001. Blood, Bones and Spirit: Aboriginal Christianity in an East Kimberley Town. Melbourne: Melbourne University Press.

Merlan, F. 1988. Gender in Aboriginal social life: a review. In R.M. Berndt and R. Tonkinson (eds), Social Anthropology and Australian Aboriginal Studies: A Contemporary Overview, pp. 17-76. Canberra: Aboriginal Studies Press.

Merlan, F. 1991. Women, productive roles, and monetisation of the 'service mode' in Aboriginal Australia: perspectives from Katherine, Northern Territory. The Australian Journal of Anthropology 2: 259-92.

Merlan, F. 1992. Male-female separation and forms of society in Aboriginal Australia. Cultural Anthropology 7: 169-93.

Meyers, D.T. 1989. Self, Society, and Personal Choice. New York: Columbia University Press.

Meyers, D.T. 1997. Feminists Rethink the Self: Feminist Theory and Politics. Boulder, CO: Westview Press.

Musharbash, Y. 2010. Marriage, love magic, and adultery: Warlpiri relationships as seen by three generations of anthropologists. Oceania 80: 272-88.

Myers, F.R. 1986. Pintupi Country, Pintupi Self: Sentiment, Place, and Politics among Western Desert Aborigines. Washington: Smithsonian Institution Press; Canberra: Australian Institute of Aboriginal Studies.

Myers, F.R. 2002. Painting Culture: The Making of an Aboriginal High Art. Durham: Duke University Press.

Nelson, T.N. 1990. My story. In S. Schreiner and D. Bell (eds), This Is My Story, pp. 18-27. Geelong: Centre for Aboriginal Studies, Deakin University. 
Ono, A. 2007. Pentecostalism Among the Bundjalung Revisited: The Rejection of Culture by Aboriginal Christians in Northern New South Wales, Australia. PhD Thesis, The Australian National University, Canberra.

Ortner, S.B. 2006. Anthropology and Social Theory: Culture, Power and the Acting Subject. Durham and London: Duke University Press.

Pearson, N. 2009. Up From the Mission: Selected Writings. Melbourne: Black Inc.

Peterson, N. 2008. Just humming: the consequences of the decline of learning contexts among the Warlpiri. In J. Kommers and E. Venbrux (eds), Cultural Styles of Knowledge Transmission: Essays in Honour of Ad Borsboom, pp. 1148. Amsterdam: Aksant.

Robbins, J. 2004. The globalization of Pentecostal and charismatic Christianity. Annual Review of Anthropology 33: 117-43.

Sansom, B. 1980. The Camp at Wallaby Cross: Aboriginal Fringe Dwellers in Darwin. Canberra: Australian Institute of Aboriginal Studies.

Sansom, B. 1988. A grammar of exchange. In I. Keen (ed.), Being Black: Aboriginal Cultures in 'Settled' Australia, pp. 159-77. Canberra: Aboriginal Studies Press.

Sansom, B. 2010. The refusal of holy engagement: how man-making can fail. Oceania 80: 24-57.

Tonkinson, R. 1990. The changing status of Aboriginal women: 'free agents' at Jigalong. In R. Tonkinson and M. Howard (eds), Going It Alone? Prospects for Aboriginal Autonomy: Essays in Honour of Ronald and Catherine Berndt, pp. 125-47. Canberra: Aboriginal Studies Press. 
This text is taken from Strings of Connectedness: Essays in Honour of Ian Keen, edited by Peter Toner, published 2015 by ANU Press, The Australian National University, Canberra, Australia. 